\title{
Joint Development issues after the South China Sea arbitration: Dilemma, opportunity and China's choice*
}

\section{Zewei Yang}

Wuhan University, 430072, China, Wuhan, Hubei Province

For citation: Zewei, Yang. 2018. "Joint Development issues after the South China Sea arbitration: Dilemma, opportunity and China's choice". Vestnik of Saint Petersburg University. Law 2: 254-273. https:// doi.org/10.21638/11701/spbu14.2018.210

Since the late 1970s, the Chinese government has put forward a principle named 'Set aside dispute and pursue joint development'. However, a joint development precedent does not exist that would assure the successful application of this principle between China and other countries with claims in South China Sea region. The possibility of joint development in the South China Sea faces the following major difficulties and challenges: a lack of political will, weak practical needs, island sovereignty disputes, ambiguities in various disputed maritime areas, and the interference of external forces. The award of the South China Sea arbitration case may exert a negative impact on joint development in this area. Though China and the Philippines are less likely to jointly develop the oil and gas resources in the South China Sea, with the improvement in Sino-Philippine relations and the further development of the relationship between China and ASEAN, as well as its member states, there is a strong possibility that the two countries will achieve cooperation and joint development in the fishery domain. Moreover, China is most likely to initiate the joint development with Indonesia, in the Natuna Islands sea area, the South China Sea.

Keywords: Sino-Philippine Arbitration Case, Joint Development, the South China Sea, United Nations Convention on the Law of the Sea.

1. Introduction. In October 2013, China and Brunei published the Joint Statement Between the People's Republic of China and Brunei Darussalam in which the two countries reiterated their political will to deepen bilateral relations through cooperation in various fields, and agreed to support relevant enterprises of the two countries to carry out joint exploration and exploitation of maritime oil and gas resources (Chinanews 2013). Subsequently, China and Vietnam issued the Joint Statement on Deepening the Comprehensive Strategic Partnership of Cooperation Between China and Vietnam in the New Era (Xinhuanet 2013). The two sides agreed to have a firm grasp on the course of bilateral relations and to set up three important mechanisms for their implementation, including a Working Group for Consultation on Maritime Joint Development. On the basis of easiness to difficulty, and of a step-by-step principle, the negotiation for the boundary delimitation in the

* This article is a part of the results of the research project - "Study on International Legal Issues of Safeguarding China's National Rights and Interests” (Project No.:17JJD820006) - a Key Project of Philosophy and Social Science Research, sponsored by Ministry of Education, China.

(c) Санкт-Петербургский государственный университет, 2018 
Mouth of the Beibu Gulf (Gulf of Tonkin) made steadily progress and actively promoted the joint development of this maritime area. ${ }^{1}$

In November 2014, Chinese President XI Jinping met respectfully with Hassanal, the Sultan of Brunei, and Malaysian Prime Minister Najib Razak who were attending the $22^{\text {nd }}$ APEC Informal Leadership Meeting. In this occasion, XI pointed out that China is willing to strengthen maritime cooperation with Brunei and to make concrete progress on joint development of the South China Sea as soon as possible; and that China and Malaysia should facilitate maritime cooperation and joint development in order to promote regional peace, stability and prosperity (Xinhua News 2014). Besides, The ChinaVietnam Joint Statement issued in November 2015, reaffirmed that 'The two sides will steadily push forward the boundary delimitation negotiation on the Mouth of the Beibu Gulf and actively promote the joint development of this sea area; Meanwhile, the Working Group for the outer area of Gulf should advance the negotiations and continue to promote the maritime joint development under the Consultative Working Group, especially to strengthen cooperation in less-sensitive areas.' (People's official site 2015). Therefore, the issue of maritime joint development may become an important part of Chinese foreign relations in the very near future.

In September 2016, the relationship between China and ASEAN was further developed along with the Commemorative Summit of the $25^{\text {th }}$ Anniversary of China-ASEAN Dialogue Relations (Joint Statement 2016). Moreover, Sino-Philippine relations turned a new page since Philippine President Duterte visited China in October 2016 (Yichun 2016). In this context, is there a possibility that China and the Philippines could agree on joint development in the South China Sea? Furthermore, with which country could China cooperate first? Undoubtedly a study of these problems is of great value both theoretically and practically.

This paper is divided into seven parts. The introduction provides the background as well as the significance of the study. The second part elaborates the status quo of the joint development in the South China Sea. The third part contains the analysis of the dilemma and its relevant challenges. The fourth part discusses the influence of the Sino-Philippine Arbitration result on the South China Sea Joint Development. The fifth part explores the possibility of developing jointly the South China Sea between two states. Based on its precedent argumentation, the sixth part gives a prediction of China's choice, pointing out that with which country China is most likely to take a leading joint development in South China Sea. The seventh part is the conclusion.

2. Joint Development in the South China Sea: Current Situation. Various proposed solutions for Joint Development in the South China Sea. State governments and scholars have proposed a number of different projects for this issue, principally including:

1) Valencia's "A Spratly Solution" (Valencia 1994, 30). Under the precondition of demilitarization and suspension of sovereignty, a multinational organization, called the Multilateral Spratly Development Authority, is constituted by states involved in the Spratly Islands dispute. This organization is not only responsible for the exploration and exploitation of resources in the disputed maritime waters and

1 As early as October 2005, China National Offshore Oil Corporation (CNOOC) and the Vietnam Petroleum Corporation signed "Framework Agreement of Oil and Gas Cooperation in Beibu Gulf" in Hanoi. 
to manage conflicts among maritime users of this region; but is also responsible for fisheries management, environmental preservation, and international cooperation in scientific research and environmental protection of the region (Valencia 1985, 211-254).

2) Triple Level Plan for South China Sea. Professor Kuen-chen FU proposed that in South China Sea, the islands are part of Chinese territory, the sovereignty of these islands and its $12 \mathrm{~nm}$ territorial sea belongs to China, so it cannot be jointly developed; However, the area outside these islands and reefs is the historical waters of China's 1947 U-shaped Line, in this area, the joint development could be taken into consideration but in which China has priority; Finally, the whole South China Sea (including the Gulf of Siam ${ }^{2}$ ) area that outside the U-Shaped Line should be fully and equally shared (Zhonghai 2013, 198-217).

3) Multi-party Negotiation. Chinese scholar YingMin AN pointed out that, the dispute issues could be settled effectively and the exploitation of conflicting regions could be developed orderly only if the states involved in dispute could, bilaterally or multilaterally, equally participate and negotiate, and could formulate commonly an economic cooperation development model for the conflicted area (Yingmin, Tingting 2011, 110-115).

Practices concerning Joint Development in the South China Sea. As early as the end of the 1970s, the Chinese government put forward the principle of 'Set aside dispute and pursue joint development', trying to solve the islands sovereignty and maritime rights disputes between China and neighbouring countries (Zhenmin 2005, 18-23; Shicun 2007, 1-10). Unfortunately, over 30 years, there does not yet exist successful instances of joint development based on this principle between China and her neighbours (Principled consensus on the East China Sea issue 2008). ${ }^{3}$

Nevertheless, there does exist some joint-development practices in the South China Sea (Beckman et al 2013, 18-19; Becker-Weinberg 2014, 155-163). For instance, in the year of 1979, the Malaysian government and the Thailand government has concluded the Memorandum of Understanding between Malaysia and the Kingdom of Thailand on the Establishment of a Joint Authority for the Exploitation of the Resources in the Sea-Bed in a Defined Area of the Continental Shelf of the Two Countries in the Gulf of Thailand. ${ }^{4}$ In 1990, the two governments adopted an Agreement between the Government of Malaysia and the Government of the Kingdom of Thailand on the Constitution and other matters relating to the establishment of the Malaysia-Thailand Joint Authority 1990. Both sides achieved ultimately joint development of oil and gas resources in the Gulf of Thailand. Besides, with the aim of promoting bilateral joint development, Indonesia and Australia signed the Treaty between Australia and the Republic of Indonesia on the Zone of Co-operation in an

2 The Gulf of Thailand.

${ }^{3}$ In 2005, China and North Korea concluded a Joint Development Agreement, it was China's first joint development agreement. In June 2008, China and Japan reached a principled consensus on the East China Sea issue, both sides affirm that they will conduct cooperation in the transitional period prior to delimitation without prejudicing their respective legal positions; besides, the two sides set up a block for the joint development in the central eastern portion of the East China Sea. Moreover, Chinese enterprises welcome the participation of Japanese legal persons in the development of the existing oil and gas fields in Chunxiao in accordance with the relevant laws of China governing cooperation with foreign enterprises in the exploration and exploitation of offshore petroleum resources.

${ }^{4}$ Entered into Force 24 October 1979. 
Area between the Indonesian Province of East Timor and Northern Australia of 11 December 1989 (International Law Materials 1990, 469-537). Additionally there was the Memorandum of Understanding Concerning the Continued Operation of the Treaty Between Australia and the Republic of Indonesia on the Zone of Cooperation in an Area Between the Indonesian Province of East Timor and the Northern Australia, adopted between Australia and Indonesia (Australia-UNTAET 2000).

Moreover, in 1992, Malaysia and Vietnam signed a Memorandum of Understanding between Malaysia and the Socialist Republic of Viet Nam for the Exploration and Exploitation of Petroleum in a Defined Area of the Continental Shelf involving the Two Countries. In this case, the two sides agreed to limit the disputed area in a "block" of $1358 \mathrm{~km}^{2}$. This "block", served as the future joint operation area, is the foundation that ensured the smooth implementation of joint development (Hong Thao 2003, 147). Also in June 18, 2001, Cambodia and Thailand reached a Memorandum of Understanding between Cambodia and Thailand on the Area of Overlapping Maritime Claims to the Continental Shelf, and planned to execute Joint Development (Beckman 2013, 183). This agreement was unilaterally abolished by Thai National Assembly because of the tension between the two countries (Thai Cabinet agrees to revoke MoU 2009).

In March 16, 2009, Malaysia and Brunei signed the Exchange of Letters between Malaysia Brunei Darussalam dated 16 March 2009 in order to promote joint development cooperation (Beckman 2013, 204).

It's worth a mentioning that, in April 2005, A Tripartite Agreement on the Joint Seismic Undertaking in the Agreed Area in the South China, signed by the petroleum enterprises of China, the Philippines and Vietnam, is regarded as a historic and substantive step forward to the "Joint Development", and is served as an important measure to the implementation of the Declaration on the Conduct of Parties in the South China Sea (Zhenmin 2005, 22). In addition, Vietnam, Thailand and Malaysia have agreed in principle on the joint development in the Gulf of Thailand in 1999, despite that the size of "block" ready for codevelopment is relatively small (Hong Thao 2003, 138).

Current Dilemma in Joint Development of the South China Sea. As mentioned above, scholars from different countries proposed a variety of theoretical solutions for the joint development issues in the South China Sea. Also in reality, some of the claimant states in the South China Sea have carried out successful joint development practices, but the South China Sea joint development is still facing the following difficulties and challenges (Zewei 2011, 70-75; Beckman et al 2013, 291-311).

Lack of political will. "The political will among the countries toward the joint development is the key element to the success of the joint development negotiations" (Beckman et al 2013, 141; Yu 2007, 55). 'As a politically motivated international cooperative operation, joint development is, no matter in its previous negotiations or in its subsequent implementation, indeed affected by the political will of both sides. For example, in the 1981 The Jan Mayen Case (Iceland/Norway), the reason why two countries had been able to reach an agreement and make arrangements for the obvious benefit of Iceland was because Norway wanted to retain Iceland in NATO as an outpost against the Soviet Union' (Penghong 1998, 96-108; Richardson 1988, 443).

Similarly in the year of 2008, the China-Japan Principled Consensus on the East China Sea (Ministry of Foreign Affairs of the People's Republic of China 2008) settled on the consistent and frequent political interaction between the two countries, and was related 
closely to the successive visit of leaders of both sides. These visits were always described as 'ice-breaking', 'melting ice', 'spring' and 'warm spring' (Jianjun 2009, 292).

However, in South China Sea, the relevant countries lacked the political will to develop jointly. Although China and ASEAN countries signed the Declaration on the Conduct of Parties in the South China Sea in 2002, this Declaration is not legally binding and lacks a punishment mechanism for the violation of its spirit. ${ }^{5}$

Weak practical needs. 'International practice approves that joint development is based on realistic considerations, and possessed obvious functional characteristics' (Jianguo 2006, 50). For instance, the Agreement between the Government of the United Kingdom of Great Britain and Northern Ireland and the Government of the Kingdom of Norway relating to the Exploitation of the Frigg Field Reservoir and Transmission of gas therefrom to the United Kingdom of 10 May 1976 (Energy 1981, 1317-1324) was signed by United Kingdom and Norway in 1976 to enable the most expedient access to the oil and gas of North Sea in order to deal with the first global energy crisis (Zewei 2016, 27). Therefore, 'economic factors, such as the country's urgent need for oil and gas resources, will firstly prompt the government to find ways and to get benefit from development without delaying the development and utilization of resources due to delimitation negotiations that may even affect the state relations' (Hui 1994, 90). Just as M. J. Valencia and Masahiro Miyoshi analyzed, that 'perhaps the most important reason for countries to choose to exploit together, is out of a sense of urgency or obligation to protect their oil and gas deposits, and to maintain or strengthen relations with their neighbours' (Valencia, Miyoshi 1986, 223). However, most of the disputed waters between China and the other claimants in the South China Sea are under the actual control, management or exploitation of these claimants. The actual representation of China and its development activities in these disputed areas are extremely limited, or even inexistent. This put China in an evidently disadvantageous position. Therefore, 'in this situation, there is no necessity and urgency for the claimants to develop jointly the South China Sea with China' (Zhiguo 2006, 203).

Islands' sovereignty disputes. Article 121 of the United Nations Convention on the Law of the Sea (hereinafter referred to as the LOSC) provides that rocks which can sustain human habitation or economic life on their own shall have exclusive economic zone or continental shelf. Therefore, the sovereignty of the island is very important. Based on the current international practices, the majority of joint development programs are launched in the overlapping maritime area, and in cases where an island sovereignty dispute does not exist (Zewei 2016, 99). Therefore, many scholars even believe that 'a prerequisite for joint development is be able to resolve the relevant island's sovereignty conflict' (Jianguo 2006, 209). However, in the South China Sea, Vietnam, the Philippines, Malaysia, Brunei do exist sovereignty disputes over islands and rocks with China. Although according to the historical and jurisprudential basis that China has indisputable sovereignty over these islands, the relevant countries are reluctant to shelve disputes or to make concessions. Therefore, it's quite difficult to launch joint development of this area.

Ambiguity in various disputed maritime areas. An essential prerequisite for joint development is overlapping maritime areas (maritime zones) that are clearly recognized by both claimants (Zewei 2016. 28-29). However, the disputed area of the South China Sea is relatively vague. On the one hand, the maritime area to which states lay claim is not

${ }^{5}$ Similarly, Guidelines for the Implementation of the DOC that signed by China and ASEAN countries is also a political statement. 
clear. For example, the South China Sea dispute involves six countries and seven parties. Not only is the disputed sea area between two countries difficult to determine, but these disputes are also often related to three or more claimants. As Jalal, ambassador-at-large of Indonesian Ministry of Foreign Affairs, said, 'due to the ambiguity of the rights of the islands and rocks in the LOSC, some claimed that the rock itself or the facilities established on reefs can have continental shelf and the exclusive economic zone, which created multiple overlapping claims among countries in South China Sea, the complexity made it more difficult to determine the disputed area" (Jianguo 2006, 182). On the other hand, China's maritime claims are not specific. Although China has ratified the LOSC and promulgated the Law of the People's Republic of China on the Territorial Sea and Contiguous Zone and the Law of the People's Republic of China on the Exclusive Economic Zone and Continental Shelf, the Chinese Government only generally points out that China has undoubted sovereignty over the Spratly Islands and their surrounding waters; but the detailed scope of the territorial sea, the exclusive economic zone and the continental shelf that China claimed in South China Sea is not clearly defined. Besides, the meaning of Chinese traditional Nine-dash line is not accurately and publicly explained. So it can be seen that it's very difficult to delimitate the joint development zone and to launch the relevant work.

Interference of external forces. The interference of United States and other regional forces in the East China Sea and South China Sea issue makes things more complicated. This also, to some extent, disturbs the advancement of joint development (Zeming 2010, 3). On the one hand, the South China Sea issue is evidently being internationalized and "multi-lateralized" (Zewei 2016, 94). On the other hand, in recent years Vietnam, the Philippines and Malaysia are more and more actively developing military and economic cooperation with the United States and Japan, aiming to contend against China.

1) The United States continues to uphold 'Freedom of navigation', and takes advantage of the disputes over territories in the South China Sea to improve its Asia-Pacific arrangement. The US 'has put great attention' on the South China Sea issue since the beginning of 21st century (Song 2003, 236). In particular, the US Department of State published 'Limits in the Seas: China's Maritime Claims in the South China Sea', which unequivocally backed the so-called 'arbitration of the South China Sea' (Office of Ocean and Polar Affairs 2014). In January 30, 2016, the USS Curtis Wilbur, an Arleigh Burke-class guided missile destroyer, sailed within 12 nautical miles of the Triton Island, part of the Chinese Paracel Islands (Ministry of National Defense spokesman YANG Yujun's speech 2006). On May 10, the US Navy illegally sent the Lawrence destroyer inside 12 nautical miles of Fiery Cross Reef of the Chinese Spratly Islands (Ministry of National Defense spokesman YANG Yujun's speech 2016). On October 20, The USN guided-missile destroyer USS Decatur (DDG 73) operated near the territorial sea of the Paracel Islands (Ministry of Foreign Affairs spokesman HUA Chunying's speech 2016). On March 18, The United States and the Philippines agreed on five locations for U.S.military facilities in the Philippines under a security deal, Enhanced Defence Cooperation Agreement, the five bases are Basa Air Base, Fort Magsaysay, Antonio Bautista Air Base, Lumbia Air Base and Mactan-Benito Ebuen Air Base. In particular, the Antonio Bautista Air Base, situated on Palawan, is in close proximity to the 'disputed' rocks of South China Sea (Xinhua News 2016). In May, 2016 President Barack Obama visited Vietnam and announced the United States 
is lifting a decades-long arms embargo on that country (Xinhua News in Hanoi, Vietnam 2016).

2) Japan continues to strengthen defence cooperation with Vietnam and the Philippines. Recently, Japan has taken an active part in military exercises in the South China Sea, frequently sending ships to this region under the name of fighting against piracy, drug smuggling, illegal migration and other trans-border crimes (Zeming 2010, 132-148). In February 2015, Gen Nakatani, Japan's defence minister made it clear that 'the influence of the situation of the South China Sea to Japan is growing' (Huanqiu Military 2015). February 18, 2016, Japan Maritime Self-Defence Force and two P-3C Coast Guard vessels conducted exercises at a seaport in the Vietnamese city of Da Nang ("Japan and Vietnam's Navy..." 2016). In May 28, Japanese Prime Minister Shinzō Abe and Vietnamese Prime Minister PHAM Xuan Phuc held talks. The two sides reached a consensus on strengthening defence cooperation (Kyodo News 2016). On February 29, Japan and the Philippines signed a defence equipment transfer agreement, Japan agreed to supply the Philippines with military hardware, involving a transfer defence technology and equipment (Xinhuanet 2016).

3) The EU's has increased its involvement. The involvement of the European Union in the South China Sea issue is often expressed by the EU institution itself - very few countries have made public statements in this issue. However since 2016, the situation has changed, several EU countries began to declare their positions. In March 2016, the European Union External Action Services (EEAS) urged all claimants to resolve disputes through peaceful means, to clarify the basis of their claims, and to pursue them in accordance with international law including LOSC and its arbitration procedures (Foreign affairs \& international relations of Council of the European Union 2016). In May, at the occasion of the G7 summit, British Prime Minister David Cameron warned China that it must abide by the outcome of international arbitration on its increasingly assertive territorial claims in the South China Sea (The Guardian 2016). In early June, France's Defence Minister, Jean-Yves Le Drian, told attendees of the Shangri-La Dialogue, that France would encourage the European Union to undertake 'regular and visible' patrols in the area (The Diplomat 2016). One month later, EEAS called all the parties of LOSC to settle the maritime dispute through international juridical means and to implement the legally-binding Award (Foreign affairs \& international relations of Council of the European Union 2016).

Moreover, after Modi appointment as prime minister of India in 2014, the Indian government changed a 'Look East' policy into an 'Act East' policy (Kugelman, Vickery 2014). During Modi's visit to Washington, India and the US issued a joint declaration which pointed out that the South China Sea is of great significance to safeguard maritime security and ensure freedom of navigation (Foreign Ministry Spokesperson's Regular Press Conference 2014). Indian President Pranab Mukherjee also signed an agreement for offshore oil exploration with Vietnam just before Modi's visit to America (Kugelman 2014, 10).

Impact of Arbitration case on joint development in the South China Sea. Relevant countries' reaction to the result of arbitration. July 12, 2016, the Permanent Court 
of Arbitration issued its final ruling on the arbitration case (PCA Press Release). After the announcement of the Award, the major powers reacted differently. The United States (Assistant Secretary and Department Spokesperson John Kirby 2016), Japan (Arbitration between the Republic of the Philippines and the People's Republic of China regarding the South China Sea 2016), Australia (Australia supports peaceful dispute resolution in the South China Sea 2016), Canada (Global Affairs Canada, Canadian statement on South China Sea Arbitration 2016) reaffirm its recognition for the arbitration. They consider that award to be legally binding, and call on both sides to abide by the ruling. Besides, the attitude of European Union (Foreign affairs \& international relations of Council of the European Union 2016) and India (Statement on Award of Arbitral Tribunal on South China Sea Under Annexure VII of UNCLOS 2016) is relatively soft: they acknowledge the result of arbitration and request all parties to respect the LOSC. The Russia, however, reaffirms its support for China, opposes the interference of foreign countries in South China Sea affairs and supports a peaceful settlement of dispute (Russia's Position on the South China Sea 2016).

ASEAN countries have a variety of positions. The Philippines are undoubtedly favourable to the results of the arbitration and focus on the implementation of the arbitration award. Additionally, the Philippines is willing to resume dialogue with China on the basis of the arbitration results (Statement of the Secretary of Foreign Affairs 2016). Vietnam also welcomed the results of the arbitration, but did not declare its opinion on the specific provisions (Remarks of the Spokesperson of the Ministry of Foreign Affairs of Vietnam 2016). Singapore (MFA Spokesman's Comments on the ruling of the Arbitral Tribunal in the Philippines v China case 2016), Malaysia (Statement by Malaysia 2016), and Myanmar emphasize the rule of law and advocate solving the South China Sea issue through diplomatic and legal processes. However, in fact they actually they indirectly support the arbitration result. Besides, Indonesia and Thailand call for all parties to observe "restraint and sobriety" (Press Releases: Statement of Thailand on Peace, Stability and Sustainable Development in the South China Sea 2016). Cambodia throws its support behind China and is against the arbitration results (Lin 2016, 33).

The South China Sea Situation after the Sino-Philippine arbitration. The situation in the South China Sea after the arbitration has had a tendency to become stable, the confrontation in this area has declined. This is mainly due to the three following reasons.

Firstly, China has exercised 'great restraint' and not taken countermeasures against the results of the arbitration. On the contrary, China made the gesture of promoting regional security and mutual trust. Because China 'disinfected' the result of arbitration through public opinion and diplomatic warfare, and took substantive measures at the relevant sea area, so as to maintain stability in the South China Sea temporarily.

Secondly, countries outside the region and major ASEAN countries are worried that if they go for further action, China may respond by taking countermeasures. Therefore, in addition to the diplomatic battle, there are no concrete measures to execute the implementation of the arbitration award.

Thirdly, as the principle party in the arbitration, the Philippines, after the change of government, showed favourable attitudes toward China, similarly, the latter positively responded to the new government. ${ }^{6}$ The relations between China and the Philippines are thus at a turning point.

${ }^{6}$ From October 18 to October 22, the president of the Philippines Duterte visited China. 
Negative Impact of the Arbitration Result on the Joint Development of the South

China Sea. Some negative effects of the Sino-Philippine arbitration award may be reflected on joint development in the South China Sea.

1) The South China Sea legal battle will continue, and 'outsider' countries, or some of the South China Sea claimant countries, are likely to seize the occasion to reinforce the results of the arbitration. In the last few years, the distinctive features of determining the legal character of the dispute in the South China Sea have become clearer (Zewei 2016, 93). Recently the legal status of China's 'nine dashed-line' claim has been often challenged by the international community (Beckman 2013, 63). For example, Hilary Clinton, the then US Secretary of State criticized it at the Security Conference of the ASEAN Regional Forum in July 2011: We also call on all sides to put forward their claims on the South China Sea in a way in accord with the international law. The claims on the South China Sea should be legal claims, which rely on the facts of topography and landform (Reuters Indonesia 2011). The Philippines also strongly criticized China in this conference maintaining that there was no basis in international law for China's claims to the South China Sea (Deutsche Presse News 2011). Meanwhile, Vietnam is willing to bring claims before international arbitration (Fuguo, Shicun 2015, 97). Penghong Cai said: "Even Indonesia believes that the dotted line will affect its 'territorial integrity' because the dotted line cuts into the Natuna Islands, thus more Indonesian troops need to be "stationed" on the islands' (Penghong 2015). Moreover, claimants of the South China Sea would invoke the provisions of the LOSC in a narrow sense in favour of them in order to get sympathy and support from the international society.

2) China's maritime claims over the South China Sea will be fragmentized due to the results of the arbitration award, the maritime enforcement exercises by China is likely to become 'less and less legitimated. The Chinese government, for quite long time, claims that 'Chinese activities in the South China Sea date back to over 2,000 years. China was the first country to discover, name, explore and exploit the resources of the South China Sea Islands and the first to continuously exercise sovereign powers over them. Therefore, China has indisputable sovereignty over the South China Sea Islands. In 1947, China renamed the maritime features of the South China Sea Islands and published an official map which displayed a dotted line in the South China Sea one year later. Besides, both the Declaration of the Government of the People's Republic of China on the Territorial Sea of 1958 and the Law of the People's Republic of China on the Territorial Sea and the Contiguous Zone of 1992 expressly provide that the territory of the People's Republic of China includes, among others, the Dongsha Islands, the Xisha Islands, the Zhongsha Islands and the Nansha Islands. All those acts affirm China's territorial sovereignty and relevant maritime rights and interests in the South China Sea" (Zewei 2016). However, the arbitral tribunal concluded that China has no legal basis to claim "historic rights" to resources in the South China Sea, and it has violated the Philippines' sovereign rights in the disputed waters (PCA Press Release 2016). So it can be seen that China will face increasing international pressures caused by the result of the arbitration award, moreover, the influence of arbitration would oblige 
China to protect its sovereignty and legitimate maritime rights over the South China Sea in an environment of degraded international public opinion.

3) The result of the arbitral award may further decrease the claimant countries' intention to execute joint development with China in the South China Sea. Before the decision of the arbitration, there already exist many sovereign disputes over islands and rocks of Spratly Islands, the joint development zone is difficult to delimit, so the claimants of South China Sea are unlikely to launch co-development with China. Worse still, the result of arbitration unilaterally denies Chinese historical claims across the Nine-Dash Line area (PCA Press Release 2016), which may lead some of the South China Sea claimants take a more negative attitude toward China's joint development activities for oil and gas resources.

\section{Possibility of Sino-Philippine joint development in the South China Sea. Favour- able conditions for the Sino-Philippine joint development after the arbitration:}

1) China's willingness to cooperate bilaterally with ASEAN may get stronger. On September 7, 2016, the 19th China-ASEAN Leadership Conference and the 25th Anniversary Summit ofChina-ASEANDialogue Relations is held in Vientianef."Laos. China and the Heads of State/Government of the Member States of ASEAN issued the "Joint Statement of the 19th ASEAN-China Summit to Commemorate the 25th Anniversary of ASEAN-China Dialogue Relations: Towards a Closer ASEANChina Strategic Partnership" (2016-09-08), "the establishment of the Guidelines for Hotline Communications among Senior Officials of the Ministries of Foreign Affairs of ASEAN Member States and China in Response to Maritime Emergencies in the Implementation of the DOC" (2016-09-08), "Joint Statement of Commemorative Summit Marking the 25th Anniversary of Bilateral Dialogue Relations" (201609-08), "the Joint Statement between ASEAN and China on Production Capacity Cooperation"(2016-09-08) (Official website of Ministry of Foreign Affairs) (Official website of Ministry of Foreign Affairs 2016). These documents, on the one hand, "stress the importance of maintaining peace and stability in the South China Sea" (Xinhuanet 2016); on the other hand, they 'reiterate its commitment to regional cooperation in East Asia and continue to maintain dialogue and coordination on the basis of regional framework', and assure that it is 'committed to enhancing the ASEAN-China Strategic Partnership for mutual benefit' (Xinhuanet 2016).

2) The recent new development in Sino-Philippine bilateral relations opened up a fresh chapter. From October 18 to 21, 2016, the President Duterte of the Philippines visited China to 'normalize and develop the Sino-Philippine relations, and put the South China Sea issues back on track of bilateral dialogue and consultation" (Chinese Foreign Ministry, 2016). October 21, 2016, "Joint Statement of China and the Philippines" was officially released (Joint Statement of China and the Philippines 2016). This joint statement reaffirmed that "contentious issues are not the sum total of the China-Philippines bilateral relationship. Both sides exchange views on the importance of handling the disputes in the South China Sea in an appropriate manner.... and addressing their territorial and jurisdictional disputes by peaceful means" (Joint Statement of China and the Philippines 2016). "Both sides agree to continue discussions on confidence-building measures to increase mutual trust and confidence and to exercise self-restraint in the conduct of 
activities in the South China Sea...Both sides also agree to explore other areas of cooperation" (Joint Statement of China and the Philippines 2016).

3) China and the Philippines have attempted to develop jointly. In 2012, the oil companies of China and the Philippines negotiated the joint development issue relevant to the maritime area near Reed Bank. Manuel Pangilinan, chairman and chief executive of Philex Petroleum, a Philippine-based oil company, suggested that, since the development of the Reed Bank oil and gas resources required the enormous support of capital and technology, so he planned to introduce one or two foreign partners to participate (Manuel Pangilinan 2016). On October 23, 2013, the Philippine Energy Minister confirmed that Forum Energy, a BritishPhilippine joint venture is negotiating with China National Offshore Oil Corporation (CNOOC) about the joint exploration of oil and gas resources in Reed Bank. He called Pangilinan, the chairman of the Philex Petroleum, to adopt a commercial agreement with the Chinese oil companies so as to pave the way for the exploration of Reed Bank, which is still in dispute (Energy Minister of the Philippines recalls Pangilinan 2014). The Reed Bank, however, is the focus of a Sino-Philippine territorial dispute. China believes that Reed Bank is located in the northeast of Chinese Spratly Islands and within the scope of the 'Nine-Dash Line', which belongs to inherent Chinese territory. Meanwhile, the Philippines are in de facto control of the Reed Bank. Therefore, the attempt of Sino-Philippine joint development near this maritime area did not prove successful (Jinming 2015, 84).

Adverse conditions. As mentioned above, although Sino-Philippine relations have been restored and developed after the arbitration, there still exist some unfavourable factors that may affect joint development in the South China Sea. For example, the result of the arbitration will have a long-term negative impact on relations between the two countries; besides, the governance capability of president Duterte remains to be seen. There are still some uncertainties in the prospects of the development of Sino-Philippine relations.

To sum up, although the current Sino-Philippine relations have been fully restored and developed, there is still a very small possibility for the two countries to develop the oil and gas resources in the South China Sea jointly.

Possibility of Sino-Philippine joint development on marine fisheries. Although the field of marine joint development is mainly based on oil and gas resources exploitation, in recent years, however, some international practices reflected that the domain of joint development extended gradually to other domains such as biological resources and marine tourism (Zewei 2014, 72). In fact, in order to promote the optimized utilization of living marine resources, LOSC attaches great importance to its joint development. For instance, article 123 of LOSC explicitly provides that States bordering enclosed or semienclosed seas "shall endeavor, directly or through an appropriate regional organization, to coordinate the management, conservation, exploration and exploitation of the living resources of the sea". In addition, there are a number of joint development practices on marine biological resources in the international community. Such as Australia and Papua New Guinea's practice, in 1978, the two countries signed the Torres Strait Treaty to establish protection area and to jointly develop the fishery resources (Burmester 1982, 321-349). 
Therefore, in the context of the improvement of bilateral relations between China and the Philippines, it is probable that the two countries will launch the fisheries joint development program near Huangyan Island in the South China Sea. The cooperation may include fishing, aquaculture, and other activities.

It's worth noting that, since the visit of Philippine President Duterte in China, the fishing activities around the Huangyan Island have not been blocked by Chinese Maritime law enforcement ships (Xuan 2016). ${ }^{7}$

China's choice: with which country is China most likely to execute a pilot-joint development in the South China Sea? As mentioned above, the stable development of China's relations with ASEAN and its member states has created favourable conditions for joint development between China and other countries with claims in the South China Sea. It is indeed that China keeps good bilateral relations with Vietnam, Malaysia and Brunei, both sides expressed 'the common will to jointly develop in the South China Sea'. Moreover, there already exist joint development practices between Vietnam, Malaysia and Brunei. Even so, due to the islands' sovereignty dispute that China has with Vietnam, Malaysia and Brunei in the Spratly Islands, China is unlikely to engage in joint development with these three countries in the South China Sea. On the contrary, it is Indonesia with whom China is most likely to carry out leading joint development activity in the South China Sea.

Possibility of joint development between China and Indonesia in the Natuna waters. The favorable conditions that China and Indonesia execute joint development are mainly in the following four aspects:

1) A good relationship exists between China and Indonesia. Since the establishment of diplomatic relations between China and Indonesia, after years of rapid development, the cooperation between two countries has been fully developed, both horizontally and vertically. Especially after President Xi's visit to Indonesia in October 2013, the bilateral relationship between China and Indonesia has been upgraded to a comprehensive strategic partnership (China-Indonesia relationship has been upgraded to a comprehensive strategic partnership 2013). As a result, Sino-Indonesia relations have become one of the most important, dynamic and potential bilateral relationships between China and ASEAN countries. From the economic perspective, in 2013, the volume of Sino-Indonesia's trade amounted to 52.45 billion US dollars. Of this, Indonesia's exports to China were 22.6 billion US dollars, which amounted to $12.4 \%$ of Indonesia's total exports. Indonesia imported from China 29.85 billion US dollars, occupying 16\% of Indonesia's total imports. China has become Indonesia's largest import country and the second largest export market after Japan. At present, the security cooperation mechanism between China and Indonesia is ahead of that among all the SinoSoutheast Asia security cooperation, such as China anti-terrorism special forces in joint training with Indonesia, joint production of missiles, bilateral defence

7 According to the information of Reuters and other media, on October 28, 2016, the spokesman for the Philippine President declared that, the Philippines observed that there are not the Chinese maritime police ships around the waters of Huangyan Island. In addition, the Associated Press also said that, on October 30, 2016, the Philippine Defense Minister Lorenzana said that, aerial inspection showed that, although there are still at least four Chinese maritime police ships remain near the waters of Huangyan Island, but they no longer restraint the Philippine fishermen from the fishing in the relevant waters. 
and security consultations, bilateral maritime security agreements, bilateral naval dialogue and so forth. In 2015, the $65^{\text {th }}$ anniversary of the establishment of diplomatic relations between China and Indonesia and the $60^{\text {th }}$ anniversary of the Bandung Conference, have further developed its bilateral relations. In the future, the '21st Century Maritime Silk Road' proposed by China, will surely include Indonesia, the largest archipelago country in Southeast Asia, thus make Indonesia an important hub for "One Road" cooperation. At the same time, Indonesia's six corridor construction plan will benefit from it.

2) There is no island sovereignty dispute between China and Indonesia. In the view of the current international practices, the majority of joint development is executed in the overlapping area without territorial sovereignty disputes (Zewei 2016, 99). Many scholars also believe that the prerequisite for joint development should be the resolution of the sovereignty conflict of the relevant islands (Jianguo 2006, 209). Therefore, the island sovereignty disputes that China has with Vietnam, the Philippines, Malaysia, and Brunei affected negatively the advancement of joint development. Between China and Indonesia, however, an island sovereignty dispute does not exist. Rather, they share 50,000 square kilometers' of overlapping maritime area in the South China Sea. Besides, Indonesia has repeatedly claimed that it is not party to the islands' sovereignty dispute of the South China Sea, but will take efforts to promote the settlement of disputes by diplomatic means and continue to play the role of 'mediator' (Huiyi 2010).

3) Indonesia has the practice of joint development with other countries. In December 1989, Indonesia and Australia signed the Treaty between Australia and the Republic of Indonesia on the Zone of Co-operation in an Area between the Indonesian Province of East Timor and Northern Australia (11 December 1989). The two countries delimitated a joint development "block" and carried out the relevant activities (International Law Material 1990, 469-537). Particularly, in this case Indonesia insisted the 200-mile continental shelf claim, which could help determine the overlapping area between China and Indonesia in the Natuna waters. In addition, if China and Indonesia launch the joint development in the Natuna waters in future, much can be learned from the experience of Indonesia and Australian relations over their fairly large sea areas. These resulted in dividing the joint development zone into three parts respectively, and applied a different development mechanism (Fox 1990, 129).

4) Natuna contains rich natural gas resources (Valencia, Masahiro 1985, 231-233; Valencia 1986, 681-683). Some information shows that the Natuna gas field of two countries overlapping area in the southern of the South China Sea reserves about 1.31 trillion cubic meters' volume, which is one of the world's largest gas fields (Jinzhe 2002,113). This makes it practicable to exploit oil and gas resources in the joint development blocks, designated by the two countries in the future.

How to promote joint exploitation of China and Indonesia in Natuna sea area? Promoting Chinese and Indonesian joint development in the Natuna waters can proceed from the following aspects:

1) Let us appropriately use the successful Indonesia-Australia joint development case for reference. In 1989, the two countries co-elaborated the activities blocks, 
the joint development institutions and the relevant applicable laws including the content of dispute settlement, and so on (International Law Material 1990, 469537). Not only was the joint development regime very detailed, but also rather scientific, and thus had a more important value for reference (Moloney 1990, 273). First of all, the content of the joint development agreement between China and Indonesia can also provide more details. Secondly, in terms of the delimitation of a joint development zone, the two countries also designated three blocks, A, $\mathrm{B}, \mathrm{C}$, of which Zone A was the core development zone that was jointly managed and equally shared the benefits of the two countries; Zone B is under Chinese jurisdiction, but China has to share some of the proceeds with Indonesia; Zone $\mathrm{C}$ is under the jurisdiction of Indonesia, which contrarily has to share part of the proceeds with China. Finally, the joint administration of the joint development, namely the Common authority, can also be given a relatively more powers by the two countries.

2) Focusing on the symbolic meaning and its influence of Sino-Indonesia joint development in the Natuna waters. In "Timor-Leste v. Australia" joint development case, Australia made many concessions to make Timor-Leste to approve the joint development agreement as soon as possible. On the one hand, most of the benefits that Australia obtains from the petroleum exploitation it will give up to TimorLeste; On the other hand, Australia agreed that the joint development commission could be mainly managed by Timor-Leste. If in the Joint Commission TimorLeste appoints one more member than Australia, the designated authority would be taken by the domestic entity of Timor-Leste (Ong 2002, 80-100). Contrarily, the concessions that Australia has made are on the condition that Timor-Leste ratify the joint development agreement at first, because the implementation of the agreement can not only ensure the stability of the Timor Sea, so as to ensure the continuation of Australia's existing oil projects; but also can achieve Australia's political and economic interests. In fact, China is also facing similar problems of joint development in the South China Sea. Therefore, in the joint development negotiations between two countries, it is possible that the two parties take appropriate concessions, and make fully use of the joint development program in Natuna waters, this case can be also seen as a symbolic example.

3) Indonesia could be considered as a logistical support base of two countries' joint development. Natuna is about 1,900 kilometers from mainland China. At present, Indonesia has built a natural gas pipeline from West Natuna to Singapore and Malaysia. Therefore, if Natuna Waters can be served as the logistics support base for the joint development, both two sides can use Indonesia's existing oil and gas processing and other infrastructure, to facilitate the joint development. Furthermore, cooperation is economically feasible because of the close distance, and rapid logistical support, which may have the largest economic benefits.

3. Conclusion. The joint development in the South China Sea after the Sino-Philippine arbitration are facing new challenges and opportunities, from this study we can draw the following conclusions.

The choice of 'block' for maritime joint development does not affect the delimitation of maritime boundary. The articles 74 and 83 of LOSC provides that, before reaching 
an agreement, 'the States concerned, in a spirit of understanding and cooperation, shall make every effort to enter into provisional arrangements of a practical nature and, during this transitional period, not to jeopardize or hamper the reaching of the final agreement.' It can be seen from this 'no harm clause' that, as a type of provisional arrangement, maritime joint development activities, including the choice of 'blocks', do not affect the delimitation of maritime boundaries (Lagoni 1984, 359; Becker-Weinberg 2014, 204). As one scholar has pointed out, 'Although joint development zones may be regarded as substitution of border, but it's not necessarily do that; in most international practices, joint development is at least initially regarded as a provisional measure' (Armstrong, Forbes 1998, 356). For example, in the 'Nigeria and Sao-Tome and Principe joint development case', a treaty concluded in 2001 provides that 'nothing contained in this Treaty shall be interpreted as a renunciation of any right or claim relating to the whole or any part of the Zone by either State Party or as recognition of the other State Party's position with regard to any right or claim to the Zone or any part thereof' (Art. 4 Treaty between the Federal Republic of Nigeria and the Democratic Republic of Sao Tome 2001). In 2002 the 'Australia and Timor-Leste Joint Development' case, the two countries concluded the Timor Sea Treaty between the Government of East Timor and the Government of Australia, which provides that the treaty don't execute any prejudice to each party's position on delimitation of the permanent continental shelf of the Joint Petroleum Development Zone (Timor Sea Treaty between the Government of East Timor and the Government of Australia 2002). In addition, in 1997 Thailand and Vietnam signed a maritime delimitation agreement, but the two countries still continue to carry out the joint development activities in the 'block' zone (Hong Thao 2003, 148). Therefore, in the negotiation of the 'block' choice, it is necessary to firstly put forward the 'no damage clause', and lead the people of the respective nations to correctly understand the nature of the maritime joint development. This may not only contribute to the designation of the joint development 'block', but is also favourable to the smooth implementation of joint development.

Existence of a disputed sea area helps to delimit the maritime joint development 'block'. As mentioned above, the recognition of disputed sea areas is a prerequisite for delimiting and developing the joint exploitation 'block'. However, if one or both sides are not clear and definite in their maritime claims, it will become very difficult to define the specific scope of maritime delimitation disputes, thus make it impossible to identify potential maritime joint development 'block'. At the same time, in this situation, the international oil companies are reluctant to take risks or to invest in the its relevant joint development activities, because the legal status of this area is ambiguous (Hong Thao 2003, 148). Therefore, to some extent, further clarifying China's claims in the South China Sea and explicitly defining the disputed sea area between China and relevant countries will undoubtedly help to delimit the maritime joint development "block".

There is a no 'no gain no win' principle for maritime joint development arrangements. As a provisional arrangement, the maritime joint development activities contribute to ease or even eliminate tensions between the two countries and help to enhance mutual trust (Beckman et al 2013, 329). In fact, the choice of the 'block', the signature of joint development agreement, are both based on the recognition of each other's claims that have legitimacy to some certain extent, it's also the result of mutual compromise, therefore, an absolute "no winner or loser" principle does not exist (Fox 1990, 122; Beckman 2013, 307). For example, in the 2001 Nigeria-Sao Tome and Principe Joint Develop- 
ment case, although Nigeria obtained $60 \# \%$ proceeds of the joint development zone, it has to undertake some social development projects for Sao-Tome and Principe. On the contrary, despite the fact that Sao-Tome can only share $40 \# \%$ of the proceeds, it has achieved its objective to participate in joint development management. Moreover, this brings the OPL246 area into the joint development 'block'. This is regarded as a huge prospect and has a license to Exxon Mobil Oil Company issued by Nigeria (Art. 3 Treaty between the Federal Republic of Nigeria and the Democratic Republic of Sao Tome 2001). Another example is the 2002 "Australia and Timor-Leste joint development case", although the Australia made greater concessions to Timor-Leste in the proportion of oil revenue from joint development zone (Timor-Leste obtains 90\#\%), but the "downstream" business that Australia responsible for is also quite lucrative.

Maritime joint development cannot be done at one go. The choice of a joint development "block", the conclusion of agreement and its implementation, are all related to national interests, which usually take a long and difficult time. For example, in the "Malaysia-Thailand Joint Development" case, from the signature of the Memorandum of Understanding on Joint Development in 1979, to the formal launch of activities in 1994, it took nearly 15 years for the two countries to realise joint development. The agreement on joint operation itself took 4 years, not to mention another 11 years spent to sign "the agreement to constitute the joint authority and other affairs" of the memorandum of understanding. Besides, in the "Australia and Timor-Leste" case, although the period for establishing the cooperation zone is much faster than in the "Malaysia-Thailand" case, it still took almost 20 years from the implementation of the memorandum to actual operation. Therefore, if China wants to launch joint development activities with the relevant countries in the South China Sea, it might do well to have enough patience and mental preparation for multiple negotiations.

\section{References}

Arbitration between the Republic of the Philippines and the People's Republic of China regarding the South China Sea (Final Award by the Arbitral Tribunal). "Statement by Foreign Minister Fumio Kishida, July 12." Accessed October 1, 2017. http://www.mofa.go.jp/press/release/press4e_001204.html.

Armstrong, Patrick, Viv Forbes. 1998. Calming the Ripples: The Cooperative Management of Ocean Resources - The Falkland Islands Example and Some Southeast Asian Comparisons. Boundaries and Energy: Problems and Prospects. US: Kluwer Law International.

Australia-UNTAET, Feb. 10, 2000. Accessed October 1, 2017. http://www.austlii.edu.au/au/other/dfat/ treaties/2000/9.html.

Assistant Secretary and Department Spokesperson John Kirby, Bureau of Public Affairs, Washington, DC, "Decision in the Philippines-China Arbitration (07.12.2016)". Accessed October 1, 2017. http://www. state.gov/r/pa/prs/ps/2016/07/259587.htm.

Australia supports peaceful dispute resolution in the South China Sea. 12 July, 2016. Accessed October 1, 2017. http://dfat.gov.au/news/news/Pages/australia-supports-peaceful-dispute-resolution-in-thesouth-china-sea.aspx.

Cai, Penghong. 1998. Joint management of disputed waters: a comparative study. Shanghai: Shanghai Academy of Social Sciences Press.

Cai, Penghong. 2015. Start the $21^{\text {st }}$ Century Maritime Silk Road and Build the Peaceful South China Sea. February 6, 2015. Accessed October 1, 2017. http://cpc.people.com.cn/n/2015/0206/c18771026521311.html.

China-Indonesia relationship has been upgraded to a comprehensive strategic partnership. October 3, 2013. Accessed October 1, 2017. http://politics.people.com.cn/n/2013/1003/c1024-23099073.html. 
Chinese Foreign Ministry spokesman HUA Chunying speech during the regular press conference. October 21, 2016. Accessed October 1, 2017. http://www.fmprc.gov.cn/web/fyrbt_673021/jzhsl_673025/t1407728. shtml.

Chinanews. October 11, 2013. "Joint Statement Between the People's Republic of China and Brunei Darussalam.” Accessed October 1, 2017. http://www.fmprc.gov.cn/nanhai/eng/zcfg_1/t1029400.htm .

David, M. Ong. 2002. “The New Timor Sea Arrangement 2001: Is Joint Development Of Common Offshore Oil and Gas Deposits Mandated under International Law?" International Journal of Marine \& Coastal Law, 17 (1): 80-100.

Deutsche Presse News. 2011. July 23, 24 (8).

Elliot, L. Richardson. 1988. “Jan Mayen in Perspective." American Journal of International Law 82: 443.

Energy. 1981. 6: 1317-1324.

"Energy Minister of the Philippines recalls Pangilinan to reach an agreement with Chinese oil enterprise." World Journal (the Philippines) January 10, 2 (2014).

Foreign affairs \& international relations of Council of the European Union. "Declaration by the High Representative on behalf of the EU on Recent Developments in the South China Sea (11.03.2016)." Accessed October 1, 2017. http://www.consilium.europa.eu/en/press/press-releases/2016/03/11-hrdeclaration-on-bealf-of-eu-recent-developments-south-china-sea/.

Foreign affairs \& international relations of Council of the European Union, "Declaration on the Award rendered in the Arbitration between the Philippines and China (15.07.2016)". Accessed October 1, 2017. https://eeas.europa.eu/headquarters/headquarters-homepage/6873/declaration-on-the-awardrendered-in-the-arbitration-between-the-philippines-and-china_en.

Foreign Ministry Spokesperson's Regular Press Conference Held by Hong Lei on October 08, 2014. Accessed October 1, 2017. http://www.fmprc.gov.cn/web/fyrbt_673021/jzhsl_673025/t1198546.shtml.

Gao, Jianjun. 2009. "A Note on the 2008 Cooperation Consensus between China and Japan in the East China Sea." Ocean Development \& International Law 40: 292.

Gao, Zhiguo et al. 2006. International Law of the Sea in Theory and in Practices. Ocean Press.

Global Affairs Canada. July 21 2016. "Canadian statement on South China Sea Arbitration". Accessed October 1, 2017. http://news.gc.ca/web/article-en.do?crtr.sj1D=\&crtr.mnthndVl=11\&mthd=advSrch\&crtr. dpt $1 \mathrm{D}=6673 \& \mathrm{nid}=1102379 \& \mathrm{crtr} .1 \mathrm{c} 1 \mathrm{D}=\& \mathrm{crtr} . t \mathrm{p} 1 \mathrm{D}=1 \& \mathrm{crtr} . y \mathrm{rStrtVl}=2015 \& \mathrm{crtr} . \mathrm{kw}=\& \mathrm{crtr}$. dyStrtVl=15\&crtr.aud1D=\&crtr.mnthStrtVl=11\&crtr.page=10\&crtr.yrndVl=2018\&crtr.dyndVl=7 .

Burmester, H. 1982. “The Torres Strait Treaty: Ocean Boundary Delimitation by Agreement." American Journal of International Law 76: 321-349.

Hazel, Fox. 1990. Joint Development of offshore Oil and Gas. London: British Inst of International \& Comparative.

Huanqiu Military. February 4, 2015. "Japan Said It May Be Involved in the South China Sea Disputes, Offering Three Measures Against China Navy". Accessed October 1, 2017. http://mil.sohu.com/20150204/ n408488518.shtml.

International Law Materials. 1990. 29: 469-537.

"Japan and Vietnam's Navy exercises to "keep watch on China". February 19, 2016. Accessed October 1, 2017. http://www.cankaoxiaoxi.com/world/20160219/1079996.shtml.

Jia, Yu. 2007. "Issues and prospective on Sino-Japan joint development." Forum of World Economics \& Politics 4: 51.

Joint Statement of the 19th ASEAN-China Summit to Commemorate the 25th Anniversary of ASEAN-China Dialogue Relation: Towards a Closer ASEAN-China Strategic Partnership. September 7, 2016. Accessed October 1, 2017. http://www.fmprc.gov.cn/web/ziliao_674904/1179_674909/t1395707.shtml.

Joint Statement of China and the Philippines. October 21, 2016. Accessed October 1, 2017. http://www.fmprc. gov.cn/web/ziliao_674904/1179_674909/t1407676.shtml.

Kyodo News. May 28, 2016. Accessed October 1, 2017. http://www.kyodonews.jp/english.

$\mathrm{Li}$, Jinming. 2015. "An analysis on the prospect of China-Philippines 'Joint development' of Reed Bank's oil and gas resources." Pacific Journal 5 (23): 84.

Liang, Jinzhe. 2002. Reflections on the Development of Dispute Area in the South China Sea. Issues of the South China Sea Symposium. Hainan.

Liu, Fuguo, Wu Shicun. 2015. The South China Sea Situation Assessment Report in 2014. South China Sea situation assessment report. Center for Security Study in Taiwan.

Liu, Lin. 2016. "The Sino-ASEAN Relations after the South China Sea Arbitration Award." World Affairs 18: 33.

Liu, Zhenmin. 2005. "The Basic Position of China on the Settlement of Maritime Disputes." China Ocean Law Review 2: 18-23. 
"Manuel Pangilinan wants to bring Chinese enterprise to explore jointly oil in Reed Bank". June 25, 2016. World Journal (the Philippines) 2.

Mark, J. Valencia, Miyoshi, M. 1986. "Southeast East Sea: Joint Development of Hydrocarbons in Overlapping Claims Areas?” Ocean Development \& International Law 16: 211-254.

Mark, J.Valencia. 1986. "Taming Troubled Waters: Joint Development of Oil and Mineral Resources in Overlapping Claims Areas." Journal of San Diego Law Review 23: 681-683.

Mark, J. Valencia. 1994. "A Spratly Solution." Far Eastern Economic Review March 31: 30.

Michael, Kugelman, Raymond E. Vickery. October 10, 2014. From "Look East" towards "Act East": Asia Pivot Policy of India. available at Japanese Diplomat Website. Accessed October 1, 2017. https://thediplomat. com/2014/10/from-looking-east-to-acting-east-indias-own-pivot-to-asia.

MFA Spokesman's Comments on the ruling of the Arbitral Tribunal in the Philippines $v$ China case under Annex VII to the 1982 United Nations Convention on the Law of the Sea (UNCLOS). 12 July 2016. Accessed October 1, 2017. https://www.mfa.gov.sg/content/mfa/media_centre/press_room/pr/2016/201607/ press_20160712_2.html.

Ministry of Foreign Affairs of the People's Republic of China. 2008. "China - Japan Principled Consensus on the East China Sea Issue, made on 18 June 2008." Accessed October 1, 2017. http://www.fmprc.gov.cn/ eng/xwfw/s2510/2535/t466632.htm.

Ministry of Foreign Affairs spokesman HUA Chunying's speech on US warships unauthorized access to my Xisha territorial waters. October 21, 2016. Accessed October 1, 2017. http://www.fmprc.gov.cn/web/ fyrbt_673021/dhdw_673027/t1407844.shtml.

Ministry of National Defense spokesman YANG Yujun's speech on US warships unauthorized access to my Xisha territorial waters. January 20, 2006. Accessed October 1, 2017. http://www.mod.gov.cn/ shouye/2016-01/30/content_4638277.htm;

Ministry of National Defense spokesman YANG Yujun's speech on US warships unauthorized access to my Nansha territorial waters. May 10, 2016. Accessed October 1, 2017. http://www.mod.gov.cn/ shouye/2016-05/10/content_4655672.htm.

Moloney G. J.. 1990. "Australian Indonesian Timor Gap Zone of Cooperation: A New Offshore Petroleum Regime." Journal of Energy and Natural Resources Law 8: 273.

Nguyen, Hong Thao. 2003. "Vietnam and Joint Development in the Gulf of Thailand." Asian Yearbook of International Law 8: 138-148.

Office of Ocean and Polar Affairs, Bureau of Oceans and International Environmental and Scientific Affairs in the Department of State, Limits in the Seas: China's Maritime Claims in the South China Sea. December 5, 2014. Accessed October 1, 2017. http://www.state.gov/e/oes/ocns/opa/c16065.htm.

Official website of Ministry of Foreign Affairs, the People's Republic of China. September 8, 2016. Accessed October 1, 2017. http://www.fmprc.gov.cn/web/ziliao_674904/1179_674909/t1395707.shtml.

PCA Press Release: The South China Sea Arbitration (the Republic of the Philippines v. The People's Republic of China). July 12, 2016. Accessed October 1, 2017. https://pca-cpa.org/en/news/pca-press-release-thesouth-china-sea-arbitration-the-republic-of-the-philippines-v-the-peoples-republic-of-china.

People's official site. China-Viet Nam Joint Statement. November 6, 2015. Accessed October 1, 2017. http:// politics.people.com.cn/n/2015/1106/c1001-27786514.html.

Press Releases: Statement of Thailand on Peace, Stability and Sustainable Development in the South China Sea. 12 July, 2016. Accessed October 1, 2017. http://www.mfa.go.th/main/en/media-center/14/68341Statement-of-Thailand-on-Peace,-Stability-and-Sust.html.

"Principled consensus on the East China Sea issue." June 19, 2008. People's Daily 4.

Rainer, Lagoni. 1984. "Interim Measures Pending Maritime Delimitation Agreements." American Journal of International Law 2 (78): 359.

Remarks of the Spokesperson of the Ministry of Foreign Affairs of Viet Nam on Viet Nam's reaction to the issuance of the Award by the Tribunal constituted under Annex VII to the United Nations Convention on the Law of the Sea in the arbitration between the Philippines and China. 12 July 2016. Accessed October 1, 2017. http://www.mofa.gov.vn/en/tt_baochi/pbnfn/ns160712211059.

Reuters Indonesia. July 23, 2011. Accessed October 1, 2017. https://www.reuters.com/places/indonesia.

Robert, Beckman, Townsend-Gault, Ian, Schofield, Clive, Davenport, Tara, Bernard, Leonardo. 2013. Beyond Territorial Disputes in the South China Sea: Legal Framework for the Joint Development of Hydrocarbon Resources. UK: Edward Elgar Publishing Limited, 2013.

Robert, Beckman. 2013. Beyond Territorial Disputes in the South China Sea: Legal Framework for the Joint Development of Hydrocarbon Resources. UK: Edward Elgar Publishing Limited.

Russia's Position on the South China Sea. July 14, 2016. Accessed October 1, 2017. http://www.mid.ru/en/ web/guest/foreign_policy/news/-/asset_publisher/cKNonkJE02Bw/content/id/2354135\#13. 
Statement of the Secretary of Foreign Affairs. 12 July, 2016. Accessed October 1, 2017. http://www.dfa.gov.ph/ newsroom/dfa-releases/9900-statement-of-the-secretary-of-foreign-affairs-2.

Statement by Malaysia. 13 July, 2016. Accessed October 1, 2017. http://www.kln.gov.my/web/guest/archieve.

Statement on Award of Arbitral Tribunal on South China Sea Under Annexure VII of UNCLOS. July 12, 2016. Accessed October 1, 2017. http://mea.gov.in/press-releases.htm?dtl/27019/Statement_on_Award_of_ Arbitral_Tribunal_on_South_China_Sea_Under_Annexure_VII_of_UNCLOS.

Thailand Observers. November 11, 2009. "Thai Cabinet agrees to revoke MoU (2001 Memorandum of Understanding between Cambodia and Thailand on the Area of Overlapping Maritime Claims to the Continental Shelf) on overlapping waters with Cambodia." Accessed October 1, 2017. http://www. thailandobservers.com/thai-cabinet-agrees-to-revoke-mou-on-overlapping-waters-with-cambodia.

The Guardian. "David Cameron: China must abide by ruling on South China Sea." May 25, 2016. Accessed October 1, 2017. https://www.theguardian.com/world/2016/may/25/david-cameron-china-rulingsouth-china-sea-the-hague-philippines.

The Diplomat. June 06, 2016. "French Defense Minister to Urge EU South China Sea Patrols." Accessed October 1, 2017. http://thediplomat.com/2016/06/french-defense-minister-to-urge-eu-south-chinasea-patrols.

Timor Sea Treaty between the Government of East Timor and the Government of Australia. 20 May, 2002.

"Treaty between Australia and the Republic of Indonesia on the Zone of Co-operation in an Area between the Indonesian Province of East Timor and Northern Australia of 11 December 1989." International Law Material, 29 (1990): 469-537.

Treaty between the Federal Republic of Nigeria and the Democratic Republic of Sao Tome and Principe on the Joint Development of Petroleum and other Resources, in respect of Areas of the Exclusive Economic Zone of the Two States. 21 February 2001. Accessed October 1, 2017. http://www.un.org/Depts/los/ LEGISLATIONANDTREATIES/PDFFILES/TREATIES/STP-NGA2001.PDF.

Vasco, Becker-Weinberg. 2014. Joint Development of Hydrocarbon Deposits in the Law of the Sea. Springer.

Wu, Shicun. 2007. "Joint Development": An Ad HOC Solution to the South China Sea Dispute." China Ocean Law Review 2: 1-10. Accessed October 1, 2017. http://www.fmprc.gov.cn/mfa_eng/zili ao_665539/3602_665543/3604_665547/t18023.shtm.

Xiao, Jianguo. 2006. Joint Development of Offshore Oil \& Gas Across the International Maritime Boundaries. Ocean Press.

Yang, Zewei. 2011. "The Principle of "Shelving Disputes and Joint Development: Dilemma and Wayout." Journal of Jiangsu University (Social Science Edition) 3 (13): 70-75.

Yang, Zewei. 2014. "Development tendency of maritime joint development." Oriental Law 3: 72.

Yang, Zewei. 2016. "Building the 21st-Century Maritime Silk Road: Its Impact on the Peaceful Use of the South China Sea." China and WTO Review 1 (2): 94.

Yang, Zewei. 2016. International Legal Issues on Joint Development in the Sea. Social Science Academic Press.

Yann-Huei, Song. 2003. "The Overall Situation in the South China Sea in the New Millennium: Before and After the September 11 Terrorist Attacks." Ocean Development \& International Law July-September: 236.

Yingmin, Liu Tingting. 2011. "The south China sea dispute of regional economic cooperation development model construction." Journal of Contemporary Asia-Pacific Studies 5: 110-115.

Yu, Hui. 1994. "Joint Development of Mineral Resources - An Asian Solution." Asian Yearbook of International Law 2: 90.

Yu, Yichun. 2016. "A welcome for turning a new page of Sino-Philippine Relations." People's Daily November 1.

Zeng, Huiyi. July 10, 2016. "Indonesia Should Pay Great Attention to the Pivot Points on the South China Sea Issue.” Accessed October 1, 2017. http://www.guancha.cn/zenghuiyi/2016_07_10_366936_s.shtml.

Zheng, Xuan. 2016. "Philippine Defense Minister said the Chinese maritime police do not stop the Philippine fishermen's activities around the water of Huangyan Island." Global Times October 30.

Zheng, Zeming. 2010. "The Big Power Factor in the Issue of the South China Sea." World Affairs Press 3.

Zhou, Zhonghai. 2013. "Legal issues on joint development in the South China Sea." Legal Reviews of Xiamen University 6: 198-217.

Xinhuanet. October 15, 2013. "Joint Statement on Deepening the Comprehensive Strategic Partnership of Cooperation Between China and Viet Nam in the New Era." Accessed October 1, 2017. http://www. fmprc.gov.cn/mfa_eng/wjb_663304/zzjg_663340/yzs_663350/gjlb_663354/2792_663578.

Xinhua News. November 11, 2014. "President XI met with five heads in APEC Summit, People's Daily". Accessed October 1, 2017. http://news.163.com/14/1111/04/AAOCDM6500014AED.html. 
Xinhuanet. February 29, 2016. "Japan and the Philippines signed arms agreements to take what they need." Accessed October 1, 2017. http://news.xinhuanet.com/world/2016-02/29/c_128763255.htm.

Xinhua News in Hanoi Vietnam. May 23, 2016. "Obama announced the lifting of arms embargo on Vietnam." Accessed October 1, 2017. http://news.xinhuanet.com/english/2016-05/23/c_135381691.htm.

Xinhua News. May 23, 2016. "U. S. lifts arms embargo on Vietnam”. Accessed October 1, 2017. https://www. shephardmedia.com/news/defence-notes/us-can-use-five-philippine-bases.

Yang, Zewei. July 1, 2016. "Beijing Immune to Manila's Arbitration." China Daily. Accessed October 1, 2017. http://www.chinadaily.com.cn/opinion/2016-06/30/content_25915808.htm.

Xinhuanet. September 8, 2016. "Chairman's Joint Statement of Commemorative Summit Marking the 25th Anniversary of Bilateral Dialogue Relations." Accessed October 1, 2017. http://world.huanqiu.com/ hot/2016-09/9415228.html.

Xinhuanet. September 8, 2016. "Joint Statement of the 19th ASEAN-China Summit to Commemorate the 25th Anniversary of ASEAN-China Dialogue Relations." Accessed October 1, 2017. http://politics. people.com.cn/n1/2016/0908/c1024-28699188.html.

Received: 10.12.2017

Accepted: 28.02.2018

Author's information:

Zewei Yang — PhD in Law, Professor; 2293639101@qq.com 